\title{
Russian Orthodoxy and the Western World
}

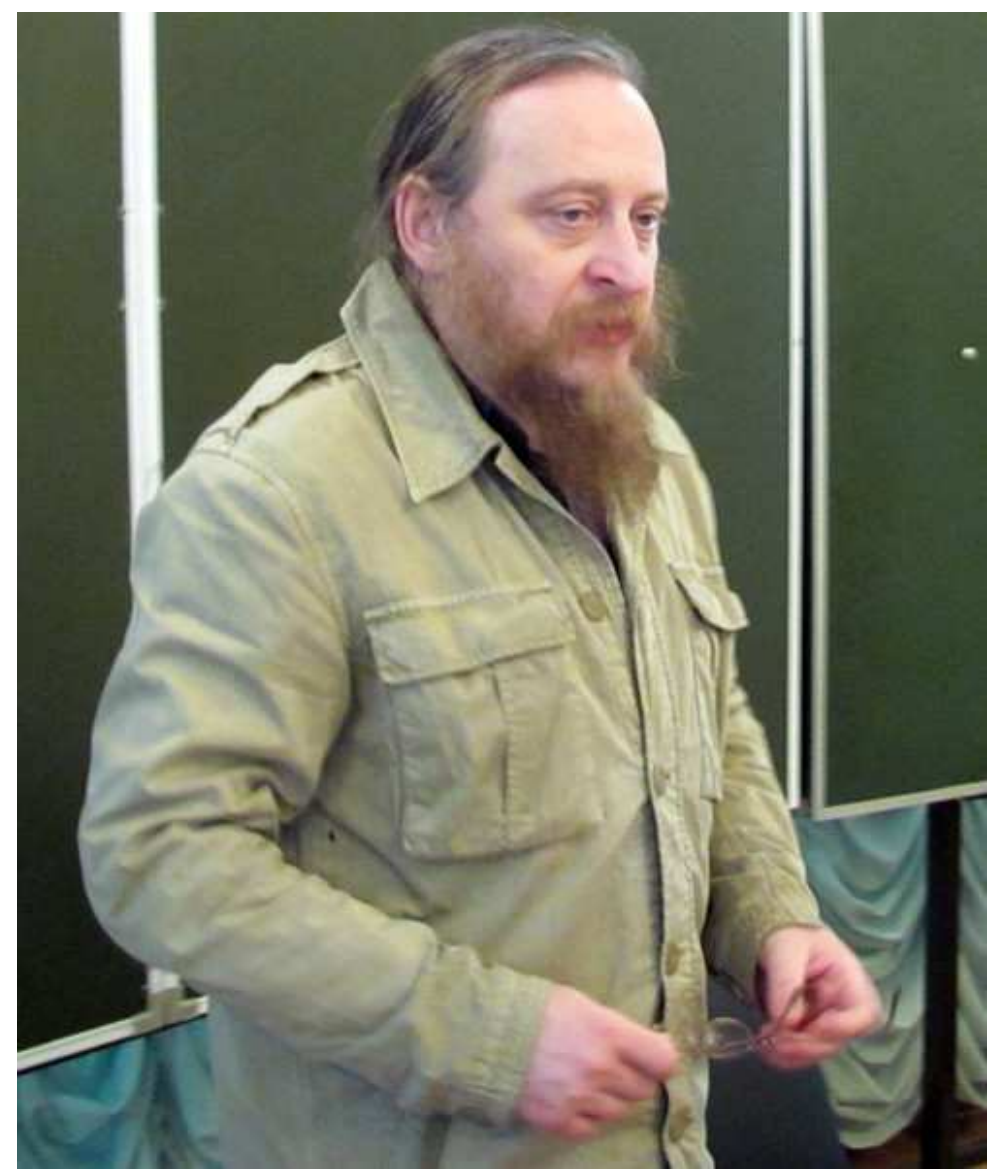

Basil Lourié born in 1962, St Petersburg, Russia. PhD and Dr habil. in philosophy. Editor in Chief of the Scrinium. Revue de patrologie, d'hagiographie critique et d'histoire ecclésiastique and of its two supplement series: Orientalia Judaica Christiana and Scripta ecclesiastica. Interests: Patristics, Christian Origins, Second Temple Judaism(s). Books in Russian: 1. Gregory of Nyssa, De hominis opificio (1995; 2nd ed., 2000) (tr. and scholarly commentary). 2. Vocation of Abraham. The Idea of the Monasticism and Its Realization in Egypt (2000). 3. History of the Byzantine Philosophy. Formative period (2006) ([some fragments on the publisher's web-site

http://www.axioma.spb.ru/z_byz_phil/in tro.htm]).

Serbian translation (2010). 4. Introduction to the Critical Hagiography (2009). 5. Russian Orthodoxy between Kiev and Moscow (2009; 2nd ed., 2010).

Tudor Petcu: It is well-known the fact that the Russian culture has always played a very important role in western societies and I would say that Westerns discovered it much better after the Second World War because of the Russian immigrants. So, please, explain us what does it mean in fact the Russian identity for the western cultures and of course for their development.

Basil Lourié: I think that the most important was not the second wave of Russian emigration (after the WWII), but the first one (in 1917 - 1922). The first wave discovered to the West a lot of Russian culture. But the second one was more Sovietized and not so useful for the West (with some exceptions, however: such as a small number of the Russian Catacomb Christians). The first Russian emigration discovered to the West Russia of "Tolstoevsky" and the Orthodoxy, sharply distinct from the Soviet Union. It became an impetus for the Western culture in some field (esp. of scholarship and religion) but not especially radical. I would prefer to avoid an overestimation of this impact. 
Tudor Petcu: The best way to understand the Russian identity is probably Orthodoxy, the most ancient Christian tradition. Do you think that different Russian immigrants who were established in West helped its citizens to discover Orthodoxy in a deeper way? We shouldn't forget that many Westerns have chosen to become Orthodox.

Basil Lourié: Indeed, some influence of Russian emigration was sensible in this respect. At least, the Russian emigration turned out a bit more successful than the Greek one (which was also enormous after the Greek catastrophe in Asia Minor in 1922). However, there was always a problem with this Russian export-quality Orthodoxy: whether the Western convert will become Orthodox or Russophiles. ROCOR (Russian Church Outside Russia) destroyed with her own hands, in the late 1960s, a successful project of the European Orthodoxy (with the Western rite and services in different European languages) by its own Exarch of Western Europe St John of Shanhai and San-Francisco. I would say that the Orthodox mission was more successful in North America than in Europe. It was even more successful in popularisation of Eastern Patristics among the Western (especially Catholic) scholars.

Finally, I would not agree with the claim that the Orthodoxy is especially important for Russian identity. Our great Orthodox and nationalistic thinker, Constantine Leontiev, realised this fact (and, thus, asked: "Do we really need Russia non-monarchic and non-Orthodox?'). Russian identity is often understood as expressed in some Christian folklore: this is hardly a right opinion, and this folklore has certainly nothing to do with true Christianity).

Tudor Petcu: Would it be correct to say that the Russian Orthodox Church Outside of Russia has meant the rebirth of some western orthodox communities?

Basil Lourié: Such ideas were close to the hearts of some its members. The most known among them is St. John of Shanhai (+ 1966). But they always were a small minority within ROCOR. The majority of both people and bishops were seeking for a "Russian club".

Tudor Petcu: What would you say about the book written by Vladimir Moss, "The Fall of Orthodox England"? I make reference to his book because he is trying to highlight some very important aspects concerning the Russian Orthodox Church.

Basil Lourié: I think that it is a good book of vulgarization, useful for the first approaching to the topic. But I forgot what is said there about the Russian Church. Anyway, Vladimir wrote a large book "The Orthodox Church on the Crossroads", where his views are exposed in an elaborated way. I cannot say that I share all his views, although, indeed, I agree with him that the only real Church under the Soviet regime was the Catacomb Church.

Tudor Petcu: Which are the main important western countries where Russian Orthodoxy has known the strongest evolution?

Basil Lourié: U.S.A. and France.

Tudor Petcu: I could not forget about one of the most important orthodox monasteries in England, called Saint John the Baptist and located in Essex. This monastery is well-known especially because of Saint Father Sophrony who was Russian and I would like you to tell me how did manage his personality to influence the evolution of Orthodoxy in England.

Basil Lourié: Fr Sophrony became very popular after his 1952 book about the Athonite Startets (Elder) Siluan. Then, Fr Sophrony became an elder himself, which provoked some tension between 
him and then the head of the Moscow Patriarchate's local diocese Metropolitan Anthony (Bloom). This is why Fr Sophrony and his monastery turned out under Constantinople. Some of the modern Orthodox believe that Fr Sophrony was a genuine Starets and so, established an important spiritual centre. Some others think otherwise and, changing a little the words, paraphrase the title of his bestsellers How I see God as He is.

Tudor Petcu: Over the years I have had the privilege to make interviews with many Western Orthodox theologians and not long time ago, I have found out that there is also what we can call the Western Orthodox Church, reborn especially in France in 20th century. This rebirth was actually a result of Eugraph Kovalevsky's actions, an immigrant from Russia, whose main purpose was the resurrection of French and Western Orthodoxy. So, how would you describe his personality as a Russian Orthodox for a new era of Orthodoxy in West?

Basil Lourié: Eugraph Kovalevsky was the heart and the driving force of the project under the omophorion of St John of Shanhai, which I have mentioned above. He lived in an extremely aggressive milieu and was not always able to see the right path in such muddle. But his missionary zeal was absolutely justified. I strongly believe that, in Western Europe, the Orthodox faith must be wrapped with the Western rite.

Tudor Petcu: As we know, there are numerous Russian orthodox theologians who lived in West such as Vladimir Lossky or Sergei Bulgakov. Given the breadth and importance of their theological work, how did they influence, from your point of view, the western Christian theology, especially the catholic one?

Basil Lourié: There is, in the West, a narrow scholarly milieu of those who study Bulgakov, Florensky, and Vladimir Soloviev. Those scholars who are interested in Patristics normally do not read them. Thus, I doubt that there is any serious influence of Bulgakov (unlike Soloviev) on the Catholic and other Western theologians. Bulgakov influenced, however, his Russian opponents Georges Florovsky and John Meyendorff who, in turn, influenced Western scholarship immediately.

Vladimir Lossky, a disciple of Etienne Gilson and a strong opponent of Bulgakov, is a quite different story. He influenced both Russian patrologists such as Meyendorff but also the Western scholars directly. He could be considered as the founder of the present-day "Neopatristic Synthesis". But Lossky was inspired by the need to write against Bulgakov's"Sophiology. So, in this way, both Bulgakov and Lossky are of importance. 